\title{
Preference-performance linkage in the neotropical spittlebug Deois flavopicta, and its relation to the Phylogenetic Constraints Hypothesis
}

\author{
C. S. S. PIRE S , ${ }^{1}$ P. W. PR I C E ${ }^{2}$ and E. G. F O N T E S ${ }^{1}{ }^{1}$ Embrapa Recursos Genéticos \\ e Biotecnologia, Brazil and ${ }^{2}$ Northern Arizona University, Flagstaff, Arizona, U.S.A.
}

\begin{abstract}
Predictions from the Phylogenetic Constraints Hypothesis were tested for the first time in a tropical system using the pasture pest Deois flavopicta Stal, which oviposits into the ground and not into plant tissues. The prediction that there is no oviposition preference-larval performance linkage was supported. The absence of such a link provides an evolutionary basis for eruptive population dynamics.

2. The effects of host species and host plant quality on the preference of ovipositing females of $D$. flavopicta and performance of their offspring on the selected host plants were tested at the population level.

3. Female oviposition behaviour was affected by the presence of the host plant. Females of $D$. flavopicta showed a strong preference to oviposit close to host plants. The number of eggs was higher in pots containing Brachiaria ruziziensis $(121.88 \pm 13.70)$ than in pots containing only the wet oviposition substrate $(5.2 \pm 1.98)$ or dry oviposition substrate $(0.067 \pm 0.067)$. Ovipositing females did not, however, discriminate between plants of Brachiaria decumbens and Axonopus marginatus and did not show a strong oviposition preference in relation to differences in plant quality (protein and fibre content). They did show oviposition preference for plants under the high watering regime. The mean number of eggs collected from pots with non water-stressed plants was $60 \%$ higher than the mean number of eggs collected on pots with water-stressed plants.

4. Although females did not show ovipositional preference, spittlebug larval performance, measured as percentage survival and duration of nymphal period, was better on plants of high protein and low fibre content. These results indicate that there is not a linkage between female oviposition preference and subsequent nymphal performance in relation to differences in protein and fibre content in the host plants. There was, however, a limited linkage between oviposition preference and nymphal performance in relation to plant water content. Females showed preference for moist sites that have high survival of newly hatched nymphs.

5. Evidence indicates that for D. flavopicta, the influences of natality and female oviposition behaviour in response to plant quality are not the major factors driving population outbreaks, which is in accordance with the Phylogenetic Constraints Hypothesis.
\end{abstract}

Key words. Insect outbreaks, nymphal performance, ovipositional preference, population dynamics.

Correspondence: Carmen Pires, Embrapa Recursos Genéticos e Biotecnologia, Cx. Postal 02372, Brasília, DF, 70.849-970, Brazil. E-mail: cpires@cenargen.embrapa.br

\section{Introduction}

Patterns in population dynamics among insect species have been detected in nature, and hypotheses to explain these patterns have been proposed, but few studies have searched for 
broad and repeatable patterns and in most cases the mechanistic explanations for these patterns have been tested poorly (Tilman, 1989; Price, 1991; Price et al., 1995a).

A new approach to population dynamics studies, which emphasises the importance of a linkage between oviposition preference and offspring performance on the population dynamics of herbivorous insects, has been proposed (Price etal., 1990, 1995a; Price, 1994). Based on studies of different latent species of gall-forming sawflies of the genus Euura and on the life-history traits and patterns of population dynamics described in the literature for a very wide range of herbivorous insects, Price etal. (1990) developed the Phylogenetic Constraints Hypothesis. This hypothesis argues that evolved life-history characteristics, such as female choice of oviposition sites, have direct consequences for the pattern of the plant-herbivore interaction and the population dynamics of herbivorous insects (Price etal., 1995a).

According to the Phylogenetic Constraints Hypothesis, the fundamental difference between latent and eruptive species is that females of latent species can evaluate plant quality as a resource for larvae, while females of eruptive species cannot (Price, 1994). The hypothesis predicts that for latent species a strong linkage between preference and performance has evolved (Price etal., 1990, 1995a; Price, 1994). The females of latent species oviposit preferentially on high quality resources where larvae must establish and usually exhibit higher survival rates. These high quality sites are rare in the plant population, so competition among females for oviposition sites can be high, however females can disperse relatively long distances in search of resources when these are locally limiting. The spacing of eggs by females prevents larval competition so that resources will not be overexploited and the host plant will not be killed. Thus these species are less likely to become serious pests.

For eruptive species, however, the hypothesis predicts a weak linkage between oviposition site selection and offspring performance (Price etal., 1990, 1995a; Price, 1994). As a consequence of female oviposition behaviour, larvae of eruptive species feed away from the oviposition site and tend to be more generalised in resource utilisation. The resource is often abundant and there is no competition for oviposition sites among females. Consequently there is no emigration of females from dense populations, resulting in high densities of larvae. Because the larvae are generalists and feed on most parts of the host plant, the plants can be killed. In these species, the nonspecific oviposition behaviour of females and the generalised feeding behaviour of larvae can allow populations to reach high densities.

The observed relationships between oviposition preference and various components of offspring performance range from good to poor correspondence [see Thompson (1988) and Thompson \& Pellmyr (1991) for a review]. Linkage between preference and performance has been recorded repeatedly in natural populations of different species of sawflies of the genus Euura (Price etal., 1987; Price, 1989; Roininen et al., 1993; Woods etal., 1996) and tested experimentally in Euura lasiolepsis Smith (Price \& Clancy, 1986; Preszler \& Price, 1988; Craig etal., 1989) and in the nymphalid butterfly
Euphydryas editha Bdv. (Singer, 1983; Singer et al., 1988). All results are consistent with the Phylogenetic Constraints Hypothesis.

Three studies have tested the preference-performance linkage in eruptive species (Legg etal., 1986; Dodge \& Price, 1991; Leyva, 1996). No evidence of a linkage between oviposition preference and offspring performance was found for the European corn borer Ostrinia nubilalis Hübner (Legg etal., 1986), the chrysomelid beetle Disonycha pluriligata LeConte (Dodge \& Price, 1991), or the western spruce budworm Choristoneura occidentalis Freeman (Leyva, 1996). For a broader general hypothesis to be developed, however, it needs to be tested in other insect groups, and it is important to test hypotheses in tropical systems.

The spittlebug-grass system offers an opportunity to test the preference-performance linkage in conditions very different from those in which the hypothesis was generated and tested previously. The spittlebug Deois flavopicta Stal (Homoptera: Cercopidae) and Euura species have very different life histories (Fontes etal., 1995; Price etal., 1995a). Deois flavopicta is a free-feeding herbivore that feeds on sap of different species of grasses, while species in the genus Euura are all plant gallers on shrubs and trees. Unlike the Euura species, spittlebug females do not oviposit in the plant tissue. Females of D. flavopicta lay eggs in the soil around the base of host plants. Ovipositing away from the host plant is apparently an old trait in the grass-feeding spittlebug group (Table 1). Different species of the genus Deois and several species of the different cercopid genera show this oviposition behaviour and all are eruptive species on different grass species.

For D. flavopicta, therefore, a low or no preferenceperformance linkage between oviposition site selection and nymphal performance is predicted. In order to test this prediction, the effects of host plant species and differences in host plant quality on oviposition preference and offspring performance in D. flavopicta were examined and the following questions were addressed: (1) Is the oviposition behaviour of the herbivore affected by the presence of the host plant? (2) If so, is there an oviposition preference in relation to the different host species and host plant quality? (3) How do plant species and plant quality affect offspring performance? (4) Is there a linkage between oviposition preference and nymphal performance?

\section{Methods}

The insect

The spittlebug D. flavopicta is a neotropical species, with a natural distribution throughout the South-East and CentralWest regions of Brazil. This species fed originally on native grasses and exhibits low population density on cerrado, the Brazilian savanna (Pires, 1998). With the introduction of exotic grasses, principally species of the genus Brachiaria from Africa, D. flavopicta populations rose to high levels and outbreak on pasture cultivated with the introduced grass species (Fontes etal., 1995). Deois flavopicta is currently the 
dominant pasture pest species in the Central-West region of Brazil.

In the Federal District of Brazil (Brasília) $\left(15^{\circ} 31^{\prime}-16^{\circ} 03^{\prime} \mathrm{S}\right.$, $\left.47^{\circ} 21^{\prime}-48^{\circ} 15^{\prime} \mathrm{W}\right)$, where this study was conducted, $D$. flavopicta has three population peaks of adults during the rainy season, from October to May, and diapauses in the egg stage during the dry season (Fontes et al., 1995). The size and timing of D. flavopicta population peaks vary from year to year in relation to the annual rainy season (Fontes et al., 1995). Adults generally emerge in November, January, and March. Diapausing eggs laid by females of the second and third generations have diapause programmed for different durations, on average 8 and 5 months, respectively. Eggs are laid in the soil close to the host plants. Nymphs feed gregariously on roots and ramets, close to the soil surface. They excrete spittle, a foamy liquid formed by the introduction of air bubbles into the watery excretion, and feed within the spittle mass. Both nymphs and adults suck on the sap and debilitate the plant. Adults generally feed on leaves, frequently killing them, probably by the injection of salivary secretions that cause phytotoxic effects.

Table 1. Examples of species of cercopids on the American continent.*

\begin{tabular}{|c|c|c|}
\hline Species & Host plants & Oviposition site \\
\hline \multicolumn{3}{|l|}{ Genus: Aeneolamia } \\
\hline A. varia posticata & Grasses & Soil \\
\hline A. v. saccharina & Sugar cane & Soil and plant debris \\
\hline A. occidentalis & Sugar cane, grasses & Soil \\
\hline A. selecta selecta & Sugar cane, grasses & Soil \\
\hline A. s. transversa & Grasses & Soil \\
\hline A. reducta montana & Grasses & Soil \\
\hline \multicolumn{3}{|l|}{ Genus: Deois } \\
\hline D. flavopicta & Grasses & Soil and plant debris \\
\hline D. incompleta & Grasses & Soil and plant debris \\
\hline D. schach & Grasses & Soil and plant debris \\
\hline \multicolumn{3}{|l|}{ Genus: Mahanarva } \\
\hline M. fimbriolata & Sugar cane, grasses & $\begin{array}{l}\text { Dead leaf sheath and } \\
\text { soil }\end{array}$ \\
\hline M. rubicunda indentata & Sugar cane, grasses & $\begin{array}{l}\text { Dead leaf sheath and } \\
\text { soil }\end{array}$ \\
\hline \multicolumn{3}{|l|}{ Genus: Prosapia } \\
\hline P. bicincta bicincta & Grasses, legume & Soil \\
\hline P. simulans & Grasses & Soil \\
\hline \multicolumn{3}{|l|}{ Genus: Zulia } \\
\hline Z. entreriana & Grasses & Soil \\
\hline Z. comlobiana & Grasses & Soil \\
\hline \multicolumn{3}{|l|}{ Other species } \\
\hline Philaenus spumarius & Legume & Grass stubble \\
\hline
\end{tabular}

*Modified from Calderón et al. (1982).

\section{The host plants}

The native grass Axonopus marginatus (Trin.) and two introduced grass species of the genus Brachiaria, B. decumbens (Stapf) and B. ruziziensis (Stapf), were selected for this study. Densities of nymphs on natural grasslands and on pasture were used as a guide to select the host plants utilised in the experiments (Pires, 1998). Axonopus marginatus is a perennial, tall-growing grass with a tussock habit and very narrow leaves (Klink, 1994). Brachiaria decumbens is a perennial grass characterised by a decumbent, stoloniferous growth habit, rooting from the lower nodes (Klink, 1994), and B. ruziziensis is a perennial grass with prostate growth that forms swards (Ferrufino \& Lapointe, 1989). Clones of the three grass species used in the experiments were collected from adjacent areas in the field and propagated vegetatively in pots.

\section{Preference-performance evaluation}

The terms preference and performance follow the definitions of Singer (1986) and Thompson (1988). Preference is a nonrandom oviposition close to the plant resource offered simultaneously in a multiple-choice cage. Performance is some measure of offspring survival, growth, or reproduction. The first experiment tested the influence of the host plant and the ovipositional substrate on ovipositional behaviour. The other three experiments investigated the linkage between ovipositional preference and nymphal performance in relation to the different host species and differences in plant quality. These experiments consisted of two parts: (1) a multiple-choice test for ovipositional preference and (2) nymphal performance on the plants chosen by females.

The multiple-choice arenas were enclosed by bottomless cages made of a metal frame with a $1.0-\mathrm{m}$ base diameter, a $0.40-\mathrm{m}$ top diameter, $0.70 \mathrm{~m}$ tall and covered with an organdy screen. In all experiments, the different treatments (potted plants) were assigned randomly to positions within cages. In expts 2 and 3, the potted plants were buried until the soil surface of the pots was level with the ground.

In all experiments, following a methodology modified from McWilliams and Cook (1975) and Kalvelage and Buzzi (1986), the soil surface of the pots was covered with a piece of paper towel over a layer of cotton to serve as the oviposition substrate. With this procedure, it was possible to standardise the humidity and texture of the oviposition substrate between replicates, and the collection of eggs was facilitated. This substrate was kept wet in all treatments in expts 2, 3, and 4.

Experiments 2 and 3 on oviposition preference were conducted in the field. The other two oviposition preference experiments and all the performance evaluation experiments were conducted in a greenhouse, where irrigation of the host plant and the humidity of the oviposition substrate were controlled. Predation on eggs and nymphs was prevented in the performance evaluation experiments. To simulate natural conditions, the greenhouse daily temperature was kept between $33.3 \pm 1.2$ and $16.9 \pm 2.1^{\circ} \mathrm{C}$, with approximately $70 \%$ air humidity, and natural photoperiod (12-13 h of light). 
In all experiments, the adults were collected randomly in pastures cultivated with Brachiaria no further than $5 \mathrm{~m}$ from a natural grassland. The sex of individual insects was determined in the laboratory, and they were released into experimental cages. Oviposition preference was evaluated at the population level, i.e. the number of eggs laid by groups of females was counted. Brachiaria spp. meadows were the only source of abundant insects, so there was a potential bias in preference studies resulting from females conditioned to these host plant species. The results do not, however, indicate such an effect.

\section{Oviposition preference}

Experiment 1. Three choices of sites for oviposition were offered to the females: a pot with the soil surface covered by completely dry cotton and paper towel, a pot with the soil surface covered by wet cotton and paper towel, and a pot planted with the host grass $B$. ruziziensis with the soil surface covered by wet cotton and paper towel. Fifteen males and 15 females were placed in each of the 15 replicated cages and kept in the cages for 4 days.

Experiment 2. Spittlebug oviposition preference was measured between two grass species: A. marginatus and $B$. decumbens. Females were offered both host plants in 20 replicated cages. A total of 25 males and 25 females was released in each cage. Fifteen pairs were released initially and kept in the cages for 5 days. The oviposition substrate and the remaining live adults were then removed, the oviposition substrate was replaced, and 10 more pairs were released in all repetitions and kept in the cages for 5 days. The number of eggs laid in each replicate by the 25 females was recorded.

Experiment 3. This experiment measured the effects of host plant quality, in terms of total protein and fibre content, on the oviposition preference and performance of D. flavopicta. Plants of $A$. marginatus and $B$. decumbens with and without fertilisation were offered to the females in a multiple-choice cage, totalling four different choices for oviposition in each replicate, with a total of 40 replicates. A total of 25 pairs were released in each cage. Fifteen pairs were released initially and kept in the cages for 5 days, after which the ovipositional substrate and remaining live adults were removed. The ovipositional substrate was replaced and 10 more pairs were released in all repetitions and kept in the cages for 5 days. The number of eggs laid in each replicate by the 25 females was recorded.

The plants were fertilised with the equivalent of $50 \mathrm{~kg} \mathrm{ha}^{-1}$ Ouro Verde (20-15-15 N-P-K) fertiliser 1 week before the beginning of the preference test, and three times during evaluation of nymphal performance. Plants were irrigated three times a week until soil saturation. Given 7 days for the plants to respond to the treatment, samples of leaves and stems were taken from plants of the four treatments and analysed for protein and fibre content. Samples of leaves and stems were taken from plants again 60 days after the beginning of fertilisation and analysed for fibre content. The analysis of total protein and fibre contents was performed according to the techniques of de Oliveira (1981) and Goering and Van Soest (1970), respectively.

Experiment 4. This experiment measured the effects of water supply on host plant growth and oviposition preference and performance of D. flavopicta. Plants of B. ruziziensis submitted to high and low watering regimes were offered to the females in multiple-choice cages. Fifteen male-female pairs were released in each of 15 replicated cages and kept there for 4 days.

The high- and low-water treatments were watered twice and once a week, respectively. The watering regime began 3 weeks before the beginning of the preference test and was extended to the same interval during performance evaluation. Plants received $250 \mathrm{ml}$ of water at each irrigation. After 3 weeks of the watering regime, samples of leaves and stems were taken from plants of the two treatments and analysed for water content. After 6 weeks of treatment, during the nymphal performance evaluation, 15 plants each of the high and low watering treatments were taken and the number of stems per plant was counted. The length of 10 stems taken randomly from each plant was also measured.

Data analysis. The oviposition preference for a combination of host plant and different oviposition substrates (expt 1) and for plants growing under different fertiliser regimes (expt 3) was tested using Friendman's test, a nonparametric rank procedure for testing the equality of treatment means in randomised block designs. When a significant difference was found among treatments, the Student-Newman-Keuls test, a multiple testing procedure, was used. The oviposition preference for different host species (expt 2) and for plants growing under different watering regimes (expt 4) was tested using a paired $t$-test. Each cage was used as a replicate. In all tests, the null hypothesis was rejected if $P<0.05$.

Differences in host plant quality in relation to fertilisation were tested with ANOVA followed by Student-Newman-Keuls multiple comparison test. The responses of host plants to different water regimes were tested with one-way ANOVA and $t$-test.

\section{Performance evaluation}

The relationship between adult female size and fecundity was measured. If female size were a good predictor of fecundity, it could be used as a measure of offspring performance. A pair of male and female spittlebugs was caged on potted B. ruziziensis within $24 \mathrm{~h}$ after female emergence. The cages were checked daily until the death of each female and the number of eggs was counted. The relationship between the number of eggs laid and the length of female wings was tested using correlation analysis (Pearson Product Moment Correlation).

The progeny from the preference tests were collected as eggs from treatments of expts 2, 3, and 4, and incubated in growth chambers. For expts 2 and 3, recently emerged nymphs 
were transferred to the base of host plants that had been submitted to the same conditions as the plants from which the eggs were collected. In expt 4, fully developed eggs were placed on moist paper under a layer of cotton at the base of plants treated with low or high water regimes. This procedure allowed the nymphs to hatch. Three days after infestation, the empty egg chorions were removed and plants were examined for the presence of a spittle mass. With this procedure, the effect of the water regime on the capacity for feeding initiation by newly hatched nymphs could be evaluated. Nymphs of all experiments were examined periodically until the final moult to determine the length of the nymphal stage and survival. Adults were collected, their sexes determined, then stored in a freezer for later measurement of wing length.

Data analysis. The survivorship of spittlebug nymphs was analysed for dependence on host species and host quality with a chi-squared test. Average length of nymphal stage and length of female wing were analysed by Tukey's multiple comparison test, when a significant $F$-value was evident.

\section{Results}

\section{Oviposition preference}

Influence of host plant presence. Host plant and substrate moisture influenced the oviposition behaviour of D. flavopicta. The order of oviposition preference was: host plant + wet oviposition substrate $>$ wet oviposition substrate without host plant $>$ dry oviposition substrate without plant (Friedman's test, $\chi^{2}=27.85$, d.f. $=2, P<0.001 ;$ Fig. 1$)$.

Influence of host plant quality. The fertilisation and water treatments altered host plant quality. The response to fertilisation differed between the two grass species in relation to protein content. Plants of $B$. decumbens responded to fertilisation with greater protein increases than did plants of $A$. marginatus (Table 2). Total protein contents did not differ

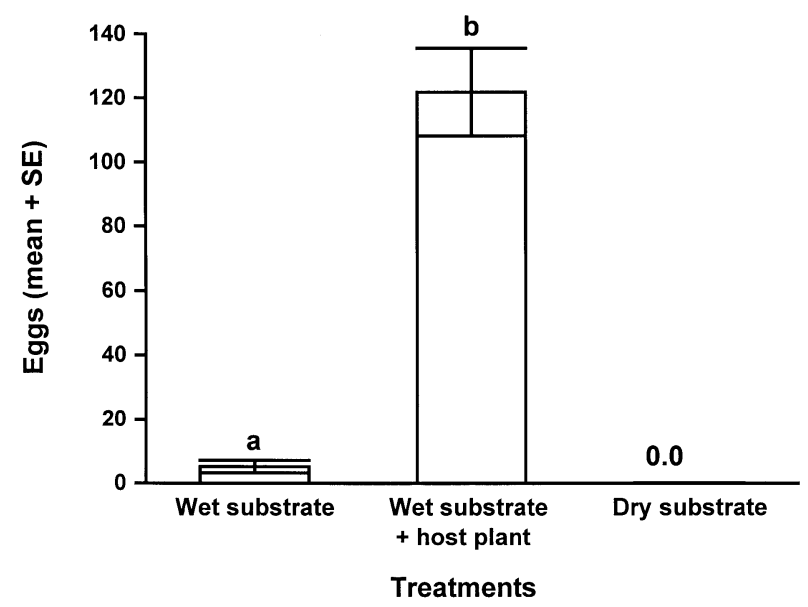

Fig. 1. Oviposition site preference of Deois flavopicta females. The treatments were offered in multiple-choice cages. Different letters above the columns indicate a significant difference between means (Student-Newman-Keuls, $n=15, P<0.05$ ).

Table 2. Total protein and fibre content in leaves and ramets of plants of Brachiaria decumbens and Axonopus marginatus with and without nitrogen, phosphorous, and potassium treatment.

\begin{tabular}{llll}
\hline & $\begin{array}{l}\text { Total protein } \\
\text { content* (7 days } \\
\text { after treatment) }\end{array}$ & $\begin{array}{l}\text { Fibre content } \dagger \\
\text { (7days after } \\
\text { treatment) }\end{array}$ & $\begin{array}{l}\text { Fibre content } \dagger \\
\text { (60 days after } \\
\text { treatment) }\end{array}$ \\
\hline B. decumbens & $7.20 \pm 0.65 \mathrm{a} \ddagger$ & $64.65 \pm 0.06 \mathrm{~b}$ & $62.69 \pm 1.54 \mathrm{a}$ \\
B. decumbens + NPK & $15.27 \pm 0.57 \mathrm{~b}$ & $62.37 \pm 0.20 \mathrm{c}$ & $63.64 \pm 1.27 \mathrm{a}$ \\
A. marginatus & $8.47 \pm 0.46 \mathrm{a}$ & $77.82 \pm 0.21 \mathrm{a}$ & $69.94 \pm 0.70 \mathrm{~b}$ \\
A. marginatus +NPK & $10.89 \pm 0.01 \mathrm{c}$ & $77.97 \pm 0.38 \mathrm{a}$ & $70.11 \pm 0.24 \mathrm{~b}$ \\
\hline
\end{tabular}

*Values of protein content expressed as total protein $(\mathrm{g})$ in $100 \mathrm{~g}$ of dry weight.

$\dagger$ Values of total neutral detergent fibre (pectin, cellulose, lignin, and nonsoluble nitrogen in acid detergent) expressed as per cent of dry weight. $\ddagger$ Means followed by the same letter do not differ $(P<0.05$, d.f. $=2$, Student-Newman-Keuls multiple comparison test $)$.

Table 3. Effect of two water regimes on plants of Brachiaria ruziziensis.

\begin{tabular}{|c|c|c|c|}
\hline & \multicolumn{2}{|l|}{ Plant growth } & \multirow{2}{*}{$\begin{array}{l}\text { Plant water content } \\
(\% \text { of dry weight })^{*} \\
(\text { mean } \pm \mathrm{SE})\end{array}$} \\
\hline & $\begin{array}{l}\text { Number of shoots } \\
(\text { mean } \pm S E)\end{array}$ & $\begin{array}{l}\text { Shoot length }(\mathrm{cm}) \\
(\text { mean } \pm \mathrm{SE})\end{array}$ & \\
\hline High water & $31.21 \pm 2.87 \mathrm{a}$ & $15.86 \pm 1.22 \mathrm{a}$ & $268.48 \pm 4.46 \mathrm{a}$ \\
\hline Low water & $\begin{array}{l}23.15 \pm 1.13 \mathrm{~b} \\
P=0.015\end{array}$ & $\begin{array}{l}11.22 \pm 0.85 \mathrm{~b} \\
P=0.005\end{array}$ & $\begin{array}{l}243.28 \pm 4.83 \mathrm{~b} \\
P=0.011\end{array}$ \\
\hline
\end{tabular}

*Plant water content (PWC) was recorded on a dry weight basis $\{\mathrm{PWC}=100 \times[$ (fresh weight-dry weight $) /$ dry weight $]\}$. 


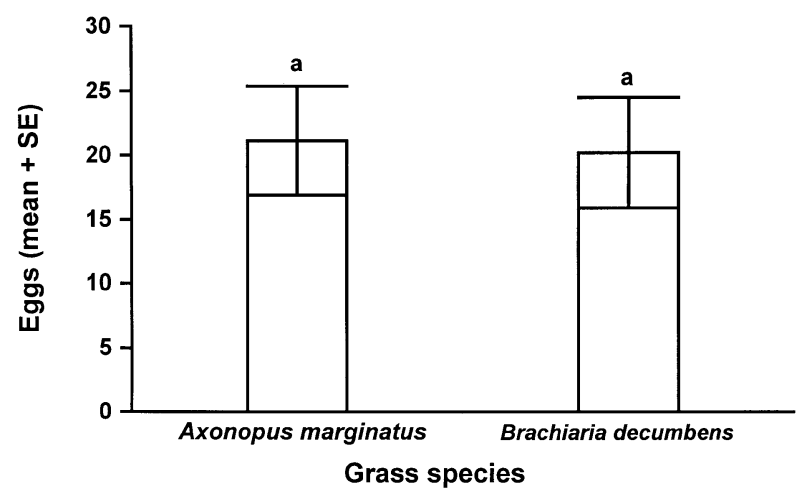

Fig. 2. Oviposition site preference of Deois flavopicta females when two grass species were offered in the same multiple-choice cage. Same letters above the columns indicate no significant difference between means $(t=0.177$, d.f. $=19, n=20, P=\mathrm{NS})$.

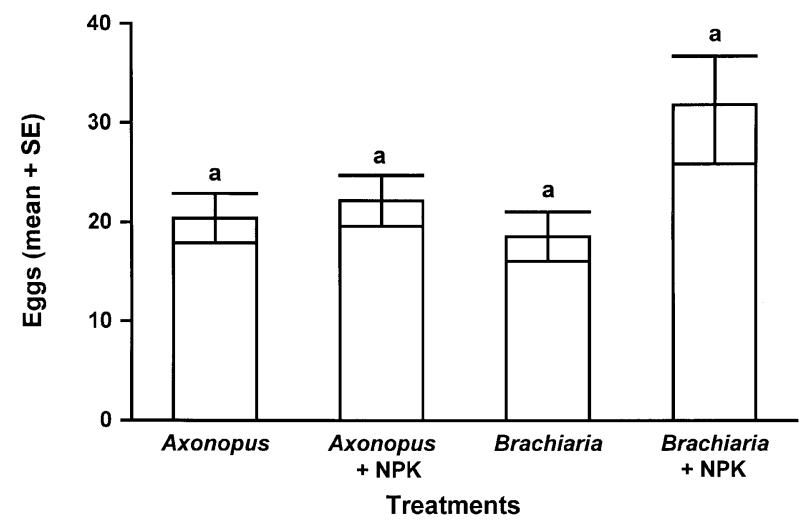

Fig. 3. Oviposition site preference of Deois flavopicta females when two grass species subjected to different nitrogen, phosphorous and potassium levels were offered in the same multiple-choice cage. Same letters above the columns indicate no significant difference between means (Friedman's test, $X^{2}=7.144$, d.f. $=3, n=40, P=\mathrm{NS}$ ).

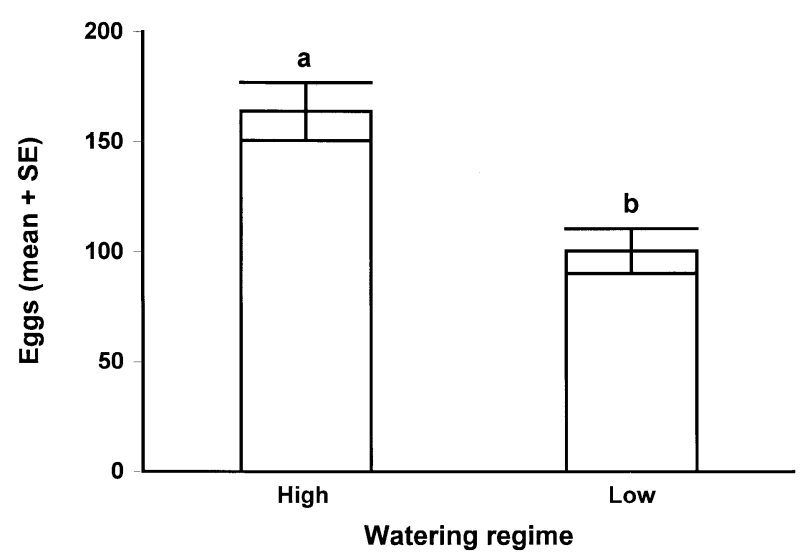

Fig. 4. Oviposition site preference of Deois flavopicta females when plants of Brachiaria ruziziensis subjected to different watering regimes were offered in the same multiple-choice cage. Different letters above the columns indicate a significant difference between means $(t=3.936$, d.f. $=28, n=29, P<0.001)$.

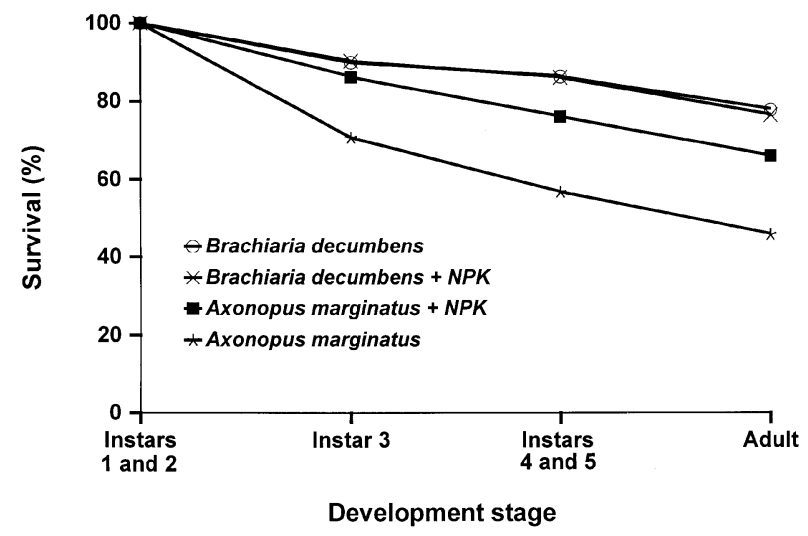

Fig. 5. Survivorship of nymphs of Deois flavopicta reared on two grass species subjected to different nitrogen, phosphous and potassium levels. Cohorts started with nymphs that initiated feeding on plants: B. decumbens, $n=198 ; B$. decumbens $+\mathrm{NPK}, n=361 ; A$. marginatus, $n=317 ;$ A. marginatus $+\mathrm{NPK}, \quad n=414 \quad\left(X^{2}=92.02\right.$, d.f. $=3, P<0.001)$.

significantly between nonfertilised plants of both species, but fibre content on nonfertilised $B$. decumbens plants was lower than on nonfertilised $A$. marginatus plants (Table 2). Fertilisation did not alter the fibre content of either grass species. Plant water content was significantly higher in plants of the high water treatment $(t=3.64$, d.f. $=6, P<0.05$; Table 3 ). The mean number of shoots was significantly higher in the high-water treatment than in the low-water treatment $(t=2.61$, d.f. $=26$, $P<0.05$; Table 3$)$, and shoots were significantly longer in the high-water treatment than in the low-water treatment $(t=3.08$, d.f. $=25, P<0.01$; Table 3 ).

Despite the differences in plant quality, females did not show strong oviposition preference in relation to differences in plant species and plant quality. Females did not show oviposition preference when their native and introduced host plants were offered in multiple-choice cages $(t=0.177$, d.f. $=19, n=40, P=$ NS; Fig. 2$)$. Oviposition preference did not differ significantly in relation to host plant fertilisation, despite the fact that the mean number of eggs laid on fertilised plants of Brachiaria was higher than the mean number laid on the other treatments (Friedman's test, $\chi^{2}=7.144$, d.f. $=3$, $n=40, P>0.05$; Fig. 3 ). Spittlebug females, however, showed ovipositional preference for plants under the high watering regime ( $t=3.936$, d.f $=28, n=29, P<0.001$; Fig. 4 ). The mean number of eggs collected from pots with non water-stressed plants was $60 \%$ higher than the mean number of eggs collected on pots with water-stressed plants.

\section{Nymphal performance}

Fecundity was not correlated significantly with female wing length $\left(r^{2}=0.054, n=93, P=\mathrm{NS}\right)$. Because projections of future fecundity based on female size would be very imprecise, female wing size was not used as a measure of performance. Females reared on $B$. decumbens (with and without nitrogen, phosphorous, and potassium), however, were significantly 
Table 4. Nymphal developmental time and wing length of females obtained from nymphs of Deois flavopicta reared on two grass species with and without fertiliser treatment.

\begin{tabular}{llllll}
\hline & \multicolumn{2}{c}{ Developmental time (days) $*$} & & \multicolumn{2}{c}{ Female wing length $(\mathrm{cm}) \dagger$} \\
\cline { 5 - 6 } \cline { 5 - 6 } & $n$ & Mean $\pm \mathrm{SE}$ & & $n$ & Mean $\pm \mathrm{SE}$ \\
\hline B. decumbens $+\mathrm{NPK}$ & 156 & $44.15 \pm 0.49 \mathrm{ab}$ & & 125 & $0.82 \pm 0.004 \mathrm{a}$ \\
B. decumbens & 116 & $42.61 \pm 0.52 \mathrm{a}$ & & 60 & $0.82 \pm 0.006 \mathrm{a}$ \\
A. marginatus $+\mathrm{NPK}$ & 233 & $43.28 \pm 0.41 \mathrm{a}$ & & 87 & $0.79 \pm 0.004 \mathrm{~b}$ \\
A. marginatus & 136 & $46.58 \pm 0.58 \mathrm{~b}$ & & 47 & $0.78 \pm 0.006 \mathrm{~b}$ \\
\hline
\end{tabular}

Means in each column followed by the same letter do not differ: ${ }^{*} P>0.05$, Tukey multiple comparison test, $\dagger P>0.05$, Dunn's multiple comparison test.

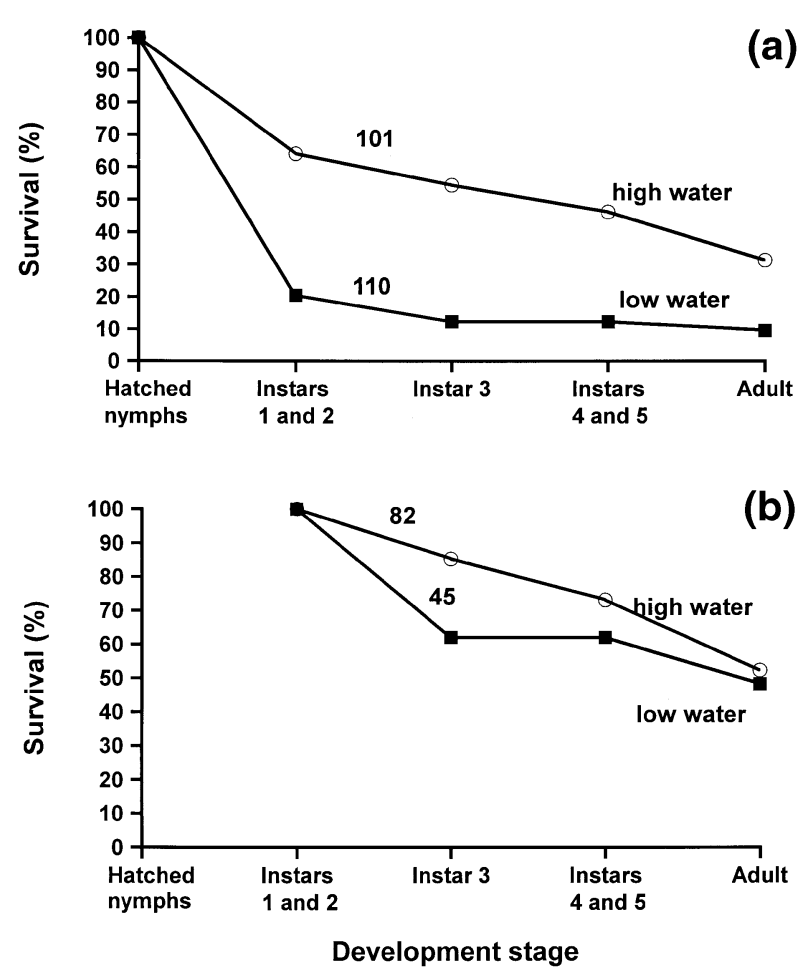

Fig. 6. Survivorship of nymphs of Deois flavopicta reared on Brachiaria ruziziensis plants subjected to different watering regimes. (a) Cohorts started with newly hatched nymphs $\left(X^{2}=23.80\right.$, d.f. $=1$, $P<0.001$ ). (b) Cohorts started with nymphs that initiated feeding on the plants $\left(X^{2}=5.35\right.$, d.f. $\left.=1, P=\mathrm{NS}\right)$. Initial number of nymphs is indicated above each curve.

larger than those reared on plants of A. marginatus (with and without nitrogen, phosphorous, and potassium) (Table 4). Offspring survival and length of nymphal cycle were therefore used as measures of nymphal performance.

There was a significant difference in nymphal performance between the two grass species (Table 4, Fig. 5). Survivorship on the introduced grass, B. decumbens, was higher $(77.78 \%)$ than on the native grass, A. marginatus (45.74\%) (Fig. 5). Plant fertilisation produced different effects on nymphal performance on the two grass species. Nymphal survivorship increased on fertilised plants of A. marginatus (65.94\%), but plant fertilisation did not produce a difference in nymphal survivorship on plants of $B$. decumbens. Nymphal survivorship on $B$. decumbens with nitrogen, phosphorous, and potassium (76.40\%) was very similar to survivorship on nonfertilised plants of the same species $(77.78 \%)$. When the total survivorship on nonfertilised plants and fertilised plants of both species was compared, this survivorship pattern was significantly nonrandom $\left(\chi^{2}=92.02\right.$, d.f. $=3, P<0.001$; Fig. 5). Fertilisation also increased the nymphal cycle on plants of $B$. decumbens (Table 4).

The nymphal performance also differed between plants of Brachiaria submitted to the low and high water regime. Total survivorship to adult stage, measured when the cohorts started with newly hatched nymphs, was higher on plants on the high water regime (Fig. 6a). This survivorship pattern was significantly nonrandom $\left(\chi^{2}=23.80\right.$, d.f. $=1, P<0.001$; Fig. 6a). When the cohort started with nymphs that had already initiated feeding on the plants, however, no difference was observed between survival of nymphs reared on plants submitted to lowand high-water treatments $\left(\chi^{2}=5.35, \quad\right.$ d.f. $=1, \quad P>0.05$; Fig. 6b). These results indicate that water stress on plants caused higher mortality of newly hatched nymphs. In addition, duration of nymphal development was significantly shorter on non water-stressed plants $(44.33 \pm 1.66$ days $)$ than on waterstressed plants $(56.79 \pm 3.41$ days $) \quad(t=-3.863, \quad$ d.f. $=57$, $P<0.001)$.

In summary, the results indicated that there is no evidence to support a strong linkage between female oviposition preference and subsequent nymphal performance. Spittlebug nymphs performed better when reared on plants with high nitrogen and low fibre content. Nevertheless, females did not show preference for ovipositional sites in relation to differences in host species and host-plant quality (protein and fibre contents). There was, however, a positive linkage between oviposition preference and nymphal performance, measured as survival of newly hatched nymphs, in relation to water plant content.

\section{Discussion}

The prediction of the Phylogenetic Constraints Hypothesis for eruptive species, that there is no link between oviposition 
preference and larval performance, was supported in part for D. flavopicta. Results presented here show limited linkage between oviposition site selection and nymphal performance in D. flavopicta, primarily for young larval survival in relation to water content in the host plants. In this species, the female oviposition behaviour of laying eggs in the soil, the freefeeding habit of the nymphs, and the long diapause of eggs reduce the probability of a strong preference-performance linkage evolving. Due to female oviposition behaviour, the newly hatched nymphs must forage for themselves. Deois flavopicta larvae must forage on the ground and initiate feeding on the ramet nearest their hatching site, without showing a strong preference among ramets based on plant quality or module size. In this situation, larvae must evolve the capability to utilise all or most ramet qualities to survive, and the population can increase and cause substantial damage on the host plants. Previous results showed a haphazard host-plant selection by third- and fourth-instar nymphs in relation to the ramet size of their host plant B. ruziziensis (Price et al., 1995b). According to Thompson (1988), for insect species that can move often between plants during development, preferences for plant species can be expressed in both adults and immatures, unlike insects that finish development on a single plant. Hence, there is a potential for selection on preference to act differently in adults and immatures (Wiklund, 1975; Thompson, 1988). In addition, because of the long diapause of eggs, 8 months and 5 months on average for eggs laid during the second and third generations, respectively (Fontes et al., 1995), females of D. flavopicta are unable to assess the quality of the food on which their offspring will feed, so the potential for selection to act on oviposition site preference is low.

Females of D. flavopicta showed a strong preference to oviposit in the substrate close to their host plants. These results are consistent with previous studies showing that a higher egg density is found in soils and plant debris close to the host plant, $B$. decumbens, than in open areas between grass clumps (Nilakhe etal., 1984; Hewitt, 1986). Hewitt (1985) showed that females also preferred to oviposit in moist, compact soils composed of small particles. In the study reported here, ovipositing females did not discriminate between plant species and did not show an ovipositional preference in relation to differences in plant quality (nitrogen and fibre contents), but they did show an oviposition preference for wet soil. The lack of oviposition preference in relation to different host species is in accordance with other research conducted with grassfeeding spittlebugs. Although Hewitt (1986) found more spittlebug eggs in pasture cultivated with $B$. decumbens than in pastures cultivated with two other Brachiaria species, experimental studies did not find strong ovipositional preference in relation to different host plants (Nilakhe, 1987; Cosenza etal., 1989). Nilakhe (1987) and Cosenza etal. (1989), working with Zulia entreriana (Homoptera: Cercopidae) and D. flavopicta, respectively, did not find a strong oviposition preference in relation to different introduced host plants offered in a multiple-choice cage. Overall, these studies support the results presented here, indicating that differences in host plant quality may not be an important factor in a female's choice of oviposition sites.
Although females did not show a strong ovipositional preference, nymphal performance, measured as percentage of survival and duration of nymphal period, was superior on plants with high protein and water contents, and low fibre contents. The lower percentage of fibre in plants of $B$. decumbens, compared to plants of A. marginatus, could explain the increased survivorship on Brachiaria. Plant tissue with lower fibre content could facilitate initiation of feeding by newly hatched nymphs. Increases in the amount of lignin in plant tissues prevent cercopid nymphs from reaching feeding sites (Hoffman \& McEvoy, 1986). Differences in plant growth and architecture may also influence nymphal establishment. Because $B$. decumbens has a decumbent, stoloniferous growth habit and A. marginatus is a tall-growing grass with a tussock habitat (Klink, 1994), plants of $B$. decumbens can provide more sites for feeding and more protection to nymphs against desiccation. In addition, the pattern of nymphal survivorship observed in the field on caged and noncaged plants of $A$. marginatus and $B$. decumbens showed some indications that plants of $B$. decumbens could also protect the nymphs against natural enemies (Pires, 1998).

Spittlebug nymphs showed better survivorship on non waterstressed plants of Brachiaria and on fertilised plants of $A$. marginatus than on water-stressed and nonfertilised plants of these two host plants, respectively (Figs 5 and 6a). Negative effects of experimental water stress and positive effects of plant fertilisation have been reported in the majority of studies of sucking insects (Waring \& Cobb, 1992). The high mortality of newly hatched nymphs reared on the low-water treatments could be a direct consequence of plant quality or could be due to the unfavourable microclimate around the plants. Newly hatched nymphs may not be able to initiate feeding on stressed plants, or they might die before reaching the plants and establishing a feeding site. When the newly hatched nymphs search for feeding sites, they are vulnerable to desiccation. The high survival of newly hatched nymphs on experimental non water-stressed plants accords with studies of the effect of moisture on changes in spittlebug population in the Federal District of Brazil. These studies indicate that low precipitation and a delay in the beginning of the rainy season have an adverse effect on survivorship of eggs and first-instar nymphs (C. S. S. Pires et al., unpublished). The amount of rain and the frequency of the rains are important factors in the mortality of newly hatched nymphs.

It has been argued that for insect species where there is a strong linkage between preference and performance, the reproductive response of females to host plant quality is the critical factor regulating population densities (Price \& Clancy, 1986; Craig et al., 1989) and should be incorporated into lifetable analyses (Preszler \& Price, 1988). According to Preszler and Price (1988), the life tables for these phytophagous insects should start with the cohort of eggs in the female ovary and include the effect of host-plant quality in reducing this cohort of eggs in the female to the cohort of eggs actually oviposited. Evidence indicates that, for D. flavopicta, a species that shows eruptive characteristics on introduced grasses, the influences of natality and female oviposition behaviour in response to plant quality are not the major factors driving population outbreaks. 
In this case, the appropriate start of the life table may well be the cohort of eggs laid in the soil.

The study reported here represents the first experimental examination of the Phylogenetic Constraints Hypothesis for a tropical insect species. Comparative studies on latent and eruptive species in tropical systems, as described above, are needed for the development of a broad, empirically based theory of insect population dynamics. The Phylogenetic Constraints Hypothesis is pluralistic because it uses divergent macroevolutionary background to explain the different patterns observed in insect population dynamics (Price, 1996).

\section{Acknowledgements}

We thank Evelyn Marques, Ana Goodman, and Edison Sujii for helpful comments that greatly improved this manuscript. We thank the field and laboratory work of the technician João S. O. Paes and the following students of the Ecology Laboratory at EMBRAPA/CENARGEN: Christhinne Resende, Cristiane Oliveira, Cristiane Sardinha, Andrea Serafini, Fernanda Gangana, and Cleber Annunciatto. This research was funded in part by a grant from the U.S. National Science Foundation (DEB-9318188), and in part by a grant from Conselho Nacional de Pesquisa e Desenvolvimento Científico e Tecnológico (CNPq/Brazil - 522315/94). Support for research in Brazil was provided by the Empresa Brasileira de Pesquisa Agropecuário (EMBRAPA). This work was completed in partial fulfilment for the requirements of a PhD by C. S. S. Pires at Northern Arizona University.

\section{References}

Calderón, M., Arango, G. \& Varela, F.A. (1982). Cercópidos Plagas de los Pastos en América Tropical. Biologia y Control. CIAT - Centro Internacional de Agricultura Tropical, Cali, Colombia.

Cosenza, G.W., Andrade, R.P., Gomes, D.T. \& Rocha, C.M.C. (1989) Resistência de gramíneas forrageiras a cigarrinha-das-pastagens. Pesquisa Agropecuária Brasileira, 24, 961-968.

Craig, T.P., Itami, J.K. \& Price, P.W. (1989) A strong relationship between oviposition preference and larval performance in a shootgalling sawfly. Ecology, 70, 1691-1699.

Dodge, K.L. \& Price, P.W. (1991) Eruptive versus noneruptive species: a comparative study of host plant use by a sawfly, Euura exiguae (Hymenoptera: Tenthredinidae) and a leaf beetle, Disonycha pluriligata (Coleoptera: Chrysomelidae). Environmental Entomology, 20, 1129-1133.

Ferrufino, A. \& Lapointe, S.L. (1989) Host plant resistance in Brachiaria grasses to the spittlebug Zulia colombiana. Entomologia experimentalis et applicata, 51, 155-162.

Fontes, E.G., Pires, C.S.S. \& Sujii, E.R. (1995) Mixed risk-spreading strategies and the population dynamics of a Brazilian pasture pest, Deois flavopicta (Homoptera: Cercopidae). Journal of Economic Entomology, 88, 1256-1262.

Goering, H.K. \& Van Soest, P.J. (1970) Forage fiber analysis (apparatus, reagents, procedures and some applications). U.S.D.A. Agricultural Handbook (ed. by United States Department of Agriculture), 1-20. Washington, DC.

Hewitt, G.B. (1985) Ovipositional preferences of the spittlebugs Zulia entreriana (Berg, 1879) and Deois flavopicta (Stal, 1854) (Homoptera: Cercopidae). Anais da Sociedade Entomológica do Brasil, 14, 198-204.

Hewitt, G.B. (1986) Spittlebug egg density in Brachiaria pastures in Central Brazil. Anais da Sociedade Entomológica do Brasil, 15, 109-112.

Hoffman, G.D. \& McEvoy, P.B. (1986) Mechanical limitations on feeding by meadow spittlebugs Philaenus spumarius (Homoptera: Cercopidae) on wild and cultivated host plants. Ecological Entomology, 11, 415-426.

Kalvelage, H. \& Buzzi, Z.J. (1986) Ciclo de vida da cigarrinha das pastagens, Deois (Pandysia) schach (Fabricius, 1787) (Homoptera, Cercopidae) à duas temperaturas. Anais da Sociedade Entomológica do Brasil, 15, 113-136.

Klink, C.A. (1994) Effects of clipping on size and tillering of native and African grasses of the Brazilian savannas (the cerrado). Oecologia, 70, 365-376.

Legg, D.E., Schenk, T.C. \& Chiang, H.C. (1986) European corn borer (Lepidoptera: Pyralidae) oviposition preference and survival on sunflower and corn. Environmental Entomology, 15, 631-634.

Leyva, K.J. (1996) Interactions among three coniferous host plants and the western spruce budworm, Choristoneura occidentalis. $\mathrm{PhD}$ thesis, Northern Arizona University, U.S.A.

McWilliams, J.M. \& Cook, J.M. (1975) Technique for rearing the twolined spittlebug. Journal of Economic Entomology, 68, 421-422.

Nilakhe, S.S. (1987) Evaluation of grasses for resistance to spittlebugs. Pesquisa Agropecuária Brasileira, 22, 767-783.

Nilakhe, S.S., Silva, A.A., Souza Filho, J.A.G. \& Paschoal, G.O. (1984) Spittlebug eggs: improved extraction method, location in pasture, and subsampling for population estimates. Anais da Sociedade Entomológica do Brasil, 13, 379-388.

de Oliveira, S.A. (1981) Método calorímetro para a determinação de nitrogenio em plantas. Pesquisa Agropecuária Brasileira, 16, 645649.

Pires, C.S.S. (1998) Influence of the host plant on the population dynamics of the spittlebug Deois flavopicta. PhD thesis, Northern Arizona University, U.S.A.

Preszler, R.W. \& Price, P.W. (1988) Host quality and sawfly populations: a new approach to life table analysis. Ecology, 69, 2012-2020

Price, P.W. (1989) Clonal development of coyote willow, Salix exigua (Salicaceae), and attack by shoot-galling sawfly, Euura exigua (Hymenoptera: Tenthredinidae). Environmental Entomology, 18, 61-68.

Price, P.W. (1991) Darwinian methodology and the theory of insect herbivore population dynamics. Annals of the Entomological Society of America, 84, 465-473.

Price, P.W. (1994) Phylogenetic constraints, adaptive syndromes, and emergent properties: from individuals to population dynamics. Researches on Population Ecology, 36, 3-14.

Price, P.W. (1996) Empirical research and factually based theory: what are their roles in entomology? American Entomologist, 42, 209-214.

Price, P.W. \& Clancy, K.M. (1986) Multiple effects of precipitation on Salix lasiolepis and populations of the stem-galling sawfly, Euura lasiolepis. Ecological Research, 1, 1-14.

Price, P.W., Roininen, H. \& Tahvanainen, J. (1987) Why does the budgalling sawfly, Euura mucronata, attack long shoots? Oecologia, 74, 1-6.

Price, P.W., Cobb, N., Craig, T., Fernandes, W., Itami, J., Mopper, S. et al. (1990) Insect herbivore population dynamics on trees and shrubs: new approaches relevant to latent and eruptive species. Insect-plant Interactions, Vol. 2 (ed. by E. A. Bernays), pp. 1-38. CRC Press, Boca Raton, Florida. 
Price, P.W., Craig, T.P. \& Roininen, H. (1995a) Working toward theory on galling sawfly population dynamics. Population Dynamics: New Approaches and Synthesis (ed. by N. Cappuccino and P. W. Price), pp. 321-338. Academic Press, San Diego, California.

Price, P.W., Andrade, I., Pires, C., Sujii, E. \& Vieira, E.M. (1995b) Gradient analysis using plant modular structure: plant architecture and insect herbivore utilization. Environmental Entomology, 24, 497-505.

Roininen, H., Price, P.W. \& Tahvanainen, J. (1993) Colonization and extinction in a population of the shoot-galling sawfly, Euura amerinae. Oikos, 68, 448-454.

Singer, M.C. (1983) Determinants of multiple host use by a phytophagous insect population. Evolution, 37, 389-403.

Singer, M.C. (1986) The definition and measurement of oviposition preference in plant-feeding insects. Insect-plant Interactions (ed. by J. Miller and T. A. Miller), pp. 65-94. Springer-Verlag, New York.

Singer, M.C., Ng, D. \& Thomas, C.D. (1988) Heritability of oviposition preference and its relationship to offspring performance within a single insect population. Evolution, 42, 977-985.

Thompson, J.N. (1988) Evolutionary ecology of the relationship between oviposition preference and performance of offspring in phytophagous insects. Entomologia experimentalis et applicata, 47, 3-14.

Thompson, J.N. \& Pellmyr, O. (1991) Evolution of oviposition behavior and host preference in Lepidoptera. Annual Review of Entomology, 36, 65-89.

Tilman, D. (1989) Discussion: population dynamics and species interactions. Perspectives in Ecological Theory (ed. by J. Roughgarden, R. M. May and S. A. Levin), pp. 89-100. Princeton University Press, Princeton, New Jersey.

Waring, G.L. \& Cobb, N.S. (1992) The impact of plant stress on herbivore population dynamics. Insect-plant Interactions, Vol. 4 (ed. by E. A. Bernays), pp. 167-226. CRC Press, Boca Raton, Florida.

Wiklund, C. (1975) The evolutionary relationship between adult oviposition preferences and larval host plant range in Papilio machaon L. Oecologia, 18, 185-197.

Woods, J.O., Carr, T.G., Price, P.W., Stevens, L. \& Cobb, N.S. (1996) Growth of coyote willow and the attack and survival of a mid-rib galling sawfly, Euura sp. Oecologia, 108, 714-722.

Accepted 26 May 1999 